\title{
Study on Development Status and Trends of Architecture Indoor
}

\section{Environmental Art Design}

\author{
Chunbao Zhang ${ }^{1}$ \\ ${ }^{1}$ Hebei Academy of Fine Arts, Xinle, Hebei, 050700
}

\begin{abstract}
KEYWORDS: Environmental Design; Environmental Art Design; Form and Function Space Environment
\end{abstract}

\begin{abstract}
Our country in recent years, the pace of urbanization continues to accelerate, with the improvement of people's living standards, people have started their own residential environment with high demand. Requires not only residential building in line with people's needs, as well as combined with each other and the surrounding environment, the architectural beauty unfolded. About the ecological aspects of urban construction, environmental design interior architecture will inevitably become the important content. Starting from the early days of our country's top ten architectural style difficult start to explore the twists and turns in the latter part of the reform and opening up a market economy for the interior design, to reflect on ecological architecture environmental design in our industry in the field of development, explore the development trend of China's mainland, and to illuminate the innovation, inheritance, development is the future of the built environment art design and orientation of the target. This paper focuses on the concept of environmental design combined with the current mode of teaching. Determine the corresponding direction of teaching, training appropriate personnel.
\end{abstract}

\section{Introduction}

With the improvement of people's living standards, people are increasingly of material to enjoy the pursuit of high-quality building system that corresponds to the social environment also corresponds to the design is complete. Environmental art design specialty is imported from abroad to an emerging professional, the corresponding technology and teaching abroad and also has some of the gap, but with the continuous improvement of talent, the profession has been constantly refined and powerful. Related institutions should seize this opportunity to give full play to their respective advantages institutions, concern for the environment art design professional discipline system, improve the teaching philosophy and guiding ideology, focusing on teaching the law of exploration and summary. Train more appropriate talent.

Environmental professional design range is very wide, it is difficult to give a definition, presents a complex profession, level of knowledge of many disciplines involved in a wide cross-composed, with the trend towards integration. This aspect of the design of the institutions concerned to focus their own personnel training, the need to seize the notch talent, training personnel corresponding to the needs of society. Currently China has strongly advocated environmental protection, pay attention to the relationship between the environment and people, the institutions concerned to seize this opportunity to pay more personnel training, the introduction of foreign ideas, focus on domestic reality, building a better home. 
According to the current environmental design professional tendency, probably including the following aspects: architecture, landscape art, urban planning, public art. The institutions need to conduct various studies on the integration of these tendencies each central element of the content and learning environment so that art and design college has its own characteristic institutions.

Purpose of environmental design is on people's living space environment in which reasonable comprehensive utilization and avoid wastage of resources, so that the natural ecological environment, social environment art. These are seen, originally designed for the target environment is people-centered, to improve the living environment for people to enjoy high quality of life.

Prospects for the development of the domestic construction indoor environmental art design is vast, quality of people's lives now is to keep up with the pace of the economy, the requirements of the indoor environment meets people's ideas, but also with contemporary reality, to keep up with the pace of international Next, it is now in the form of domestic analysis from several aspects.

\section{The Meaning of the Indoor Environment Art Design}

Indoor environmental art design only is a reasonable planning to carry out construction of internal space, rational design, construction and scientific basis, using artistic expression for people to create the indoor environment to live out environmental conservation and safety creation of a rational activity.

Indoor environmental art design and traditional interiors main difference lies in the indoor environment during the Art and Design is interior design, while focusing on the construction of the indoor substances, and also a very good concern to people living in the spiritual needs, the effective combination of good material and spirit between these two up, the indoor environment is such a people-oriented concept to gradually strengthen the level of substance on the interior design, by this concept to a large extent to meet the people's material It needs. There is also taking into account the needs of all the people living in the physical and mental aspects, to improve the quality of the indoor environment to create a rational structure, so that people living as far as possible to meet their spiritual level, so as to achieve the combination of spiritual and material blending an in-home environment.

Indoor environment requirements, reflecting the people's concept of modern life patterns change, this era of progress and economic development of modern and contemporary indivisible.

\section{The Indoor Environmental Art Design Problems}

With the development of indoor environmental art design, people in many parts of our country began to focus on art and design their own residential building in the indoor environment.

Different parts of the presentation of the interior environment art design level and the level is not the same building, is not only a different conception of the designers involved in the design, there is a different concept of the consumer, we can start from the following aspects, to analysis:

Easy to overlook its reasonable, leading blindly to the pursuit of noble and luxury. Do not pay attention to the modern reality, in line with modern and contemporary design, architectural interior environment art design emphasis should be close to life, to know the best interior design effect is still should be people-oriented, so that the people's requirements as a basis, not completely de-emphasize luxury. Only in social development, people now demand has gradually deviated from the indoor actually function, and excessive pursuit of gorgeous and beautiful style. Designers in order to meet such a fashion, it will increase the accumulation of material in the process of design to 
create a beautiful aesthetic effect, leading to the interior design gradually moving in the wrong direction.

Widespread domestic and interior design mimicry phenomenon, most of the performance is in the style of the design, modeling, and decorative materials. Phenomenon the most is when all the imitation and plagiarism somewhere has a new style, the other place will be flocked. When this phenomenon flooded, the lack of designers and will lose the innovative thinking and ability, like the interior design industry gradually into a pool of stagnant water lifeless.

In a modern interior design will be ignored ecological issues, and synthetic chemical materials turned out to be one of the most important contemporary interior decoration materials, many of which contain harmful substances, and irritating odor, not only pollute the air, but also harm people's health, which replaced the popular "housing disorder." This is a lot of modern architecture environmental design problems require people to change their ideas, continuous development of environmentally friendly products.

\section{In Determining the Content about the Interior Design}

Expand institutions in environmental design aspects of education, when students want to form an independent space awareness, understanding of buildings, mainly from the function and form, architectural appearance of the building, material selection and color matching, the building and the surrounding environment coordination. In this same time, to consider the good with the local community needs, pay attention to harmony with the local environment, taking into account the object of building services. Everything from reality, the practice of combining theory, showing the changes are consistent with the concept of human design.

With the development of society, the building can be divided into a number of suitable objects, some public buildings and private buildings, such as residential buildings will cover the definition of the villa, but not necessarily all residential homes and villas. The biggest difference is that the villa has its particularity of land, often built in a beautiful environment will mean expensive zone for detached residential nursing homes people live and rest. While living in small homes and downtown, and environmental conditions are not very beautiful, but it has some features of the villa, it does not pay attention to the construction area is large or small, nor can palatial expensive price measure, but pay attention to the unique, geared to comfort, convenience, and aesthetics. Such individual design and construction reflect the individual taste, philosophy and personality characteristics serve.

\section{The Characteristics of Small Dwellings}

In a small residential building design is the most original architectural design, by understanding and grasp the basic principles of architectural design required general procedures and basic ways and means to the building in the understanding qualitative leap.

A good small residential design should first solve the problem of coordination of its architectural and environmental surroundings, full use of the natural landscape on the local conditions so that different regions of historical and cultural traditions and aesthetic taste and endowed with a creative common integration indoor environmental art design.

Solve building a good relationship of form and function. In people-oriented aspects of the organization reasonably detailed function, it appears on the layout space free-flowing, full of a variety of changes, so that each element with inner space of an organic convergence, and the scale 
and proportion of more humane. Conducive to people's acceptance, but also show the characteristics of the indoor environment of the building, this is one of the main factors to consider. ,

In order to cultivate the ability to sketch the plane into three-dimensional model on one design capability, the ability to apply the correct specification of presentation solutions for the future relationship between indoor environmental art design can be more correctly deal between the buildings and the space environment and to create a good beginning.

The whole area is not large, but the function and taste, can give buyers a good living environment. Small residential stress is a thin design. Its designer is to allow consumers to enjoy a harmonious atmosphere inside the mini-environment. Economic benefits are mostly used materials.

A good small house, and should adapt to the surrounding environment. With the acceleration of urbanization, many of the residential environment is carefully crafted interior designer, to create a starting point, that is, taking into account the surrounding environment, according to the different surroundings starting point, the architects designed it different, not the same foothold, such as the parish house, the sound effect is stronger than ordinary residential housing, roads design, the wider the peak of easy school.

\section{Analysis of Difficulties}

Space awareness on the problem, should pay attention to the psychological impact on people's perception of space caused. The so-called functional means is multifaceted, not simply on the understanding that meets certain practical needs, but should pay attention to psychological sense of space occupants, thus stimulating occupants Language this space arising emotions and associations. Therefore, always pay attention to the design conception and practical combination, and make it as the target creation. Let create can move into their own, and also allows this function effectively throughout the various factors together, so that the space has a dual aspect of material and spiritual attributes.

Interior Design Art College students are particularly active thinking, especially in terms of beginner indoor architectural design, the trend nowadays is very keen and fashion elements, and has a good sense of form and expression, the only drawback He likes to solve problems through rational aspects of thinking and reasoning. Will in many cases only to form a hollow conceptual scheme does not go in depth, and finally to a good program but not due sublimation.

Cultivation of indoor environmental art and design aspects of the quality of designers is not a matter between day and night, it will not be able to fully resolve several issues, which is a need to continue the accumulation process, the need to break the shackles of tradition, pushed into a new, the courage to open up new areas of creativity.

Thought architect above limitations detained architectural design breakthrough above. From the beginning of the 1980s, the emergence of a lot of foreign designers to participate in China's building designs to, such as the famous Beijing Jianguo Hotel, Tianjin Grand Hyatt, Kempinski Hotel, etc., which led to the our thriving industry trend, many of the architectural style of art collide with each other, to promote the development of China's construction industry.

With the development of the construction industry, the designer's skill levels are different, resulting in a lot of messy scene. Too much emphasis on the visual space, combined with the actual ignored, so a lot of buildings out of tune with reality. Present form is that many of the architects of the country by the limitations of the original building, the building can not design a new product.

One-sided pursuit of individuality, not combined needs of the people. Many designers now consider is designed to highlight their products, taking into account the building is their product design shape, there is no direct account of changes around, this is a lot of modern architectural 
interior design issues presented. The final consideration of architectural design and is a return to the human standard, there is no humane architectural design, the equivalent of a shell, only the appearance, but not the people's favorite.

\section{Conclusion}

Times are changing, building indoor environmental art and design meet not only the people's visual concept, but also to fit the actual lives of people, and only designed look in line with the public's vision, this architectural interior design to get public recognition. It is now not only the requirements of the building in line with people's housing needs, as well as aesthetic effect, the need for building indoor environmental art designers, combined with people's actual design.

As described above, the articles so much on a comprehensive analysis of indoor environmental art design, but also illustrates some of the problems currently present in interior design and improvement and reform measures, a clear analysis of the present stage of this article Interior Design traditional, modern, postmodern, and other natural style, which also illustrates the trend in the industry to be the future development.

\section{REFERENCE:}

[1] Zhou Changji, Ya Zhou, Fu Na. China's Construction Status of The Indoor Environment of Art And Design And Development [J]. Shandong Architecture University, 2011 (26).

[2] Zou Ying, Bian Hongbin. Villa Architectural Design [M]. China Architectural Press.

[3] Yang Wenhui. Environmental Art Education [M]. People's Publishing House.

[4] Tadao Ando (Japan), Bai Lin Translation, Tadao Ando 'S Building [M]. China Building Industry Press.

[5] Liang Jieliang. Status Quo and Development Trend of Building Indoor Environmental Art and Design [M]. Technology And The Market, 2013 (9). 